\title{
SISTEM INFORMASI MANAJEMEN PERSEDIAAN PRODUKSI BUKU BERBASIS ONLINE PADA CV DIAN CEMERLANG
}

\author{
1) Natalia $^{2)}$ \\ 1) Sistem Informasi Universitas Machung \\ 2) Sistem Informasi Universitas Machung \\ E-mail: $\underline{\text { meme.susilowati@machung.ac.id } 1)}$, nataliaonly21@gmail.com

\begin{abstract}
Abstraksi
CV Dian Cemerlang merupakan sebuah perusahaan manufaktur yang berfokus memproduksi buku dengan berbagai macam jenis dan ukuran. Saat ini proses pencatatan persediaan pada perusahaan masih manual yaitu berupa berkas. Pencatatan manual tersebut menyebabkan pertukaran informasi produksi yang terpisah-pisah atau tidak saling terkait, sehingga akan lebih sulit untuk melakukan melihat history seperti pemakaian bahan baku, mengecek stok bahan baku yang habis. Untuk menyelesaikan permasalahan tersebut, maka dibuatlah sistem informasi manajemen persediaan yang dapat membantu pencatatan produksi yang berjalan yang meliputi kartu stok bahan baku, notifikasi apabila ada stok bahan baku yang berada di batas minimum, stok hasil akhir produksi. Sistem ini dibangun menggunakan metode penelitian yang terdiri dari lima tahap yaitu pengumpulan data, analisis data, design sistem, implementasi desain, dan evaluasi sistem. Hasil penelitian ini akan menghasilkan desain user interface sistem berupa kartu stok bahan baku, notifikasi stok kritis dan grafik untuk memudahkan top management melihat laporan yang berkaitan dengan produksi.
\end{abstract}

\section{Kata Kunci :}

Sistem Informasi, Produksi, Stok, Pencatatan, Persediaan

\begin{abstract}
CV Dian Cemerlang is a manufacturing company that focuses producing books in various types and sizes. Currently the company's recording process is still manual. The manual recording led to the exchange of production information is fragmentary, so it will be more difficult to perform viewed history as the use of raw materials, check stocks of raw materials are exhausted. To resolve these problems, inventory management information system made to help recording production runs that include card stock of raw materials, notification when stock of raw materials are in the minimum, and the stock of the final results of production. This system built using five stages of research method: data collection, data analysis, system design, design, implementation and evaluation system. This study will result in the user interface design of the system in the form of card stock of raw materials, critical notifications and stock charts to facilitate top management.
\end{abstract}

Keywords :

Information System, Production, Stock, Recording, Inventory

\section{Pendahuluan}

CV Dian Cemerlang merupakan perusahaan yang bergerak dalam bidang produksi buku tulis dengan berbagai merek,

diantaranya Humble ${ }^{\mathrm{TM}}$, RendahatiTM, Formality $^{\mathrm{TM}}$, dan KawaiiBook ${ }^{\mathrm{TM}}$. Desain yang unik dan produk berkualitas membuat CV Dian Cemerlang bekerjasama dengan distributor dari berbagai kota. Para distributor memesan berbagai produk dengan jumlah yang beragam sesuai dengan permintaan pasar.

Hingga saat ini proses pencatatan stok pada CV Dian Cemerlang masih manual yaitu berupa berkas. Jika ada stok bahan baku yang habis, hal tersebut baru diketahui saat proses produksi akan dilakukan. Selain itu, pencatatan manual menyebabkan perputaran informasi kurang akurat karena informasi yang ada terpisah-pisah atau tidak saling terkait, sehingga 
pencatatan manual tersebut dapat menjadi masalah bagi perusahaan di masa yang akan datang,

Berdasarkan latar belakang tersebut, maka penulis menyimpulkan bahwa CV Dian Cemerlang membutuhkan adanya sistem

informasi pengelolaan data manajemen persediaan untuk mengetahui stok bahan baku yang tersedia secara real time, sehingga pemesanan bahan baku kepada pemasok lebih

efektif, (meminimalisir keterlambatan pengadaan bahan baku) dan proses produksi dapat berjalan lancar.

\section{Dengan}

berdasarkan

pada

permasalahan diatas maka penulis bertujuan membangun sistem informasi manajemen persediaan produksi buku berbasis online pada CV Dian Cemerlang untuk memberikan informasi terkait stok bahan baku, produk jadi di gudang secara real time dan memberikan notifikasi apabila terdapat stok yang mencapai batas minimum (stok kritis).

Penulis membatasi penelitian ini pada

implementasi desain sistem informasi manajemen persediaan produksi buku berbasis online menggunakan bahasa pemrograman PHP dan database mysql. Sistem informasi manajemen persediaan produksi buku ini berfokus pada pencatatan persediaan dan penggunaan bahan baku dalam proses produksi, sehingga tidak mendukung proses pemesanan bahan baku kepada supplier. Tahapan implemetasi sistem ini menggunakan metode pengumpulan data, analisis data, design sistem, implementasi desain, dan evaluasi sistem.

Penelitian sebelumnya menghasilkan sebuah laporan hasil analisis dan desain berorientasi objek dari sistem informasi manajemen persediaan produksi buku berbasis online. Dimana laporan tersebut berisi model sistem informasi berupa workflow proses bisnis, workflow sistem yang diusulkan, diagram use case, dan rangkaian tabel relasi database. Sedangkan kontribusi dari makalah ini berupa desain user interface sistem yang merupakan hasil implementasi desain. Penelitian ini juga memberikan kontribusi sebagai bahan pustaka dalam pengembangan penelitian selanjutnya pada topik yang serupa maupun berkaitan.

\section{Tinjauan Pustaka}

Tinjauan pustaka yang terdapat pada penelitian ini terdiri dari beberapa hal yaitu, hasil dari tiga penelitian sebelumnya, rangkuman teori tentang konsep sistem informasi, sistem informasi manajemen, tahapan daur hidup pengembangan sistem, dan uraian terkait kegiatan pengembangan sistem.

\section{Rancang Bangun Sistem Informasi E- Commerce Humblebook (Studi Kasus : CV Dian Cemerlang)}

Penelitian yang dilakukan oleh Yanitra Abdi Dharmawan, seorang mahasiswi Sistem Informasi angkatan 2009 Ma Chung bertujuan untuk membantu mengembangkan bisnis $\mathrm{CV}$ Dian Cemerlang melalui internet dengan cara mempermudah pembeli untuk melihat katalog produk-produk buatan CV Dian Cemerlang [4]. Kelebihan dari penelitian yang dilakukan oleh Yanitra adalah sistem yang dibangun dapat membantu pengambilan keputusan tingkat manajer karena terdapat laporan penjualan dalam bentuk grafik. Sedangkan kelemahan penelitian yang dilakukan oleh Yanitra adalah penggunaan pemrograman ASP.NET dalam implementasi sistem, di mana pemrograman tersebut tidak open source sehingga perusahaan harus membayar sejumlah biaya untuk software tersebut dan tidak dapat menyempurnakan sistem dengan leluasa.

Pada artikel ini penulis juga akan mengembangkan program berbasis website, namun pada makalah ini penelitian akan dibangun menggunakan bahasa pemrograman open source yaitu PHP dan Mysql.

\section{Perancangan Sistem Informasi Manajemen Stok} Makanan dan Minuman pada Restoran NZIP

Penelitian yang dilakukan oleh Bangun Budiarto, Nabila Opier, Agung Dwi Saputro, Ahmad Heru Mujianto, Aldo Sahala, dan Joko Prayitno dari Program Studi Teknik Informatika AMIKOM Yogyakarta ini membahas tentang pengendalian stok makanan dan minuman pada restoran NZIP agar stok menu selalu tersedia bagi pelanggan [3]. Metode pengembangan aplikasi yang digunakan adalah metode Rapid Application Development (RAD), dengan desain perangkat lunak berorientasi objek Unified Modeling Language (UML). Sistem yang dibangun berbasis mobile bagi pelanggan dan berbasis desktop bagi pihak restoran guna mengelola dan mengatur stok makanan dan minuman. Kelebihan dari penelitian Bangun Budiarto, dkk ini terletak pada sistem notifikasi stok makanan dan minuman. Namun masih terdapat kelemahan pada penelitian yang 
dilakukan oleh Bangun Budiarto, dkk yaitu semua yang dipaparkan belum diimplementasikan (hanya berupa rancangan), sehingga tidak dapat dipastikan apakah sistem yang dirancang dapat diimplementasikan secara nyata.

Pada artikel ini penulis juga akan mengembangkan program manajemen stok, namun pada makalah ini penelitian akan dibangun untuk studi kasus CV Dian Cemerlang dan dibuat berbasis website, selain itu sistem ini juga dilakukan hingga tahap implementasi dan evaluasi sistem.

\section{Sistem Informasi Perhitungan Biaya Bahan baku Produksi Buku (Studi Kasus: CV Dian Cemerlang)}

Penelitian yang dilakukan oleh Natalia, seorang mahasiswi Sistem Informasi angkatan

2013 Ma Chung membahas tentang penghitungan kebutuhan bahan baku untuk proses produksi di CV Dian Cemerlang. [9] Tujuan dari penelitian ini adalah untuk mempermudah pemilik untuk menghitung kebutuhan bahan baku yang diperlukan dalam memenuhi pesanan dan biaya yang dibutuhkan.

Kelebihan dari penelitian ini adalah sistem yang dibangun merupakan sistem berbasis desktop di mana penggunaannya terbatas di lingkungan perusahaan, sehingga data perusahaan tidak mudah tersebarluas ke pihak luar. Sedangkan kekurangan penelitian ini adalah sistem yang dibangun belum berhubungan dengan stok persediaan bahan baku di gudang, sehingga pengguna hanya dapat mengetahui jenis dan jumlah bahan baku yang dibutuhkan.

Oleh karena itu, pada artikel ini penulis mengembangkan program berbasis website untuk menunjang pencatatan manajemen persediaan di CV Dian Cemerlang.

Penelitian ini merupakan pengembangan dari ide maupun studi kasus penelitian yang sama, namun pada penelitian ini terdapat beberapa penyempurnaan dari artikel sebelumnya. Pada artikel ini penelitian disempurnakan dengan melakukan tahap implentasi desain yaitu penerapan desain sistem ke dalam bahasa pemrograman, sehingga menghasilkan output berupa aplikasi berbasis website yang siap pakai.

\section{Rangkuman Teori}

Konsep Dasar Sistem Informasi yaitu suatu sistem yang menghubungkan kebutuhan operasional dengan kegiatan strategi dan menyediakan laporan-laporan bagi pihak yang membutuhkan [6]. Sistem Informasi Manajemen merupakan sistem berbasis komputer yang menyediakan informasi untuk pengguna yang memiliki kebutuhan yang sama [5]. Sistem dapat diartikan sebagai rangkaian prosedur yang saling berkaitan untuk melakukan kegiatan guna mencapai sasaran tertentu [6].

Daur Hidup Pengembangan Sistem terdiri dari tahap perencanaan sistem, analisis sistem, desain sistem, implementasi sistem, uji coba dan pengelolaan sistem [8]. Namun menurut Kendall \& Kendall terdapat tiga tahap utama dalam merencanakan dan mengontrol proyek yang akan dibangun agar berhasil dilaksanakan [7]. Ketiga tahap utama tersebut meliputi analisis, desain dan implementasi dan dikenal sebagai Tiga Tahap Utama atau Three Major Phases. Kegiatan yang dilakukan pada tahapan Three Major Phases dijelaskan pada tabel 1 berikut.

Tabel 1 Three Major Phases [7]

\begin{tabular}{|c|c|}
\hline Phase & Activity \\
\hline Analysis & $\begin{array}{l}\text { - Data gathering } \\
\text { - Data flow and decision } \\
\text { analysis } \\
\text { - Proposal preparation }\end{array}$ \\
\hline Design & $\begin{array}{l}\text { - } \\
\text { - } \text { Inputa design } \\
\text { - } \\
\text { - } \\
\text { Dutput design } \\
\text { Data organization }\end{array}$ \\
\hline Implementation & \begin{tabular}{|ll} 
- & Implementation \\
- & Evaluation
\end{tabular} \\
\hline
\end{tabular}

Tahap analisis terdiri dari tiga tahap yaitu pengumpulan data, analisis data dan persiapan proposal. Tahap analisis data dilakukan dengan membuat workflow, use case dan diagram aktivitas untuk memudahkan perancangan sistem.

Dalam bukunya yang berjudul Seven Steps to Mastering Business Analysis Barbara menuliskan bahwa Workflow merupakan teknik fleksibel yang perlu dipelajari oleh analis pemula di mana melalui workflow analis mendapatkan informasi berupa alur informasi dan keterlibatan pihak-pihak terkait dalam suatu proses [1].

Pengertian Usecase menurut John Satzinger yaitu gambaran dari kegiatan yang dilakukan oleh sistem, biasanya dalam menanggapi permintaan dari pengguna sistem

[11]. Activity Diagram digunakan untuk menggambarkan pengguna sistem dan kegiatan- 
kegiatan yang ada menggunakan simbol dan beralur, sehingga alur kegiatan yang dilakukan pengguna sistem pun tergambarkan dengan jelas [10].

Tahap desain terdiri dari penentuan inputan data dalam sistem, desain form input, desain form output yang dihasilkan sistem, dan perancangan database sesuai kebutuhan sistem.

Tahap implementasi sendiri terdiri dari dua tahap yaitu pembangunan sistem dan pengujian sistem. Pada tahap pembangunan sistem, desain atau rancangan sistem yang telah dibuat diimplementasikan ke dalam bahasa pemrograman PHP dan database Mysql. Tahap pengujian sistem dilakukan untuk mengetahui apakah sistem mampu menerima data yang benar dan menolak data yang salah. Pengujian sistem dilakukan dengan menggunakan blackbox testing yaitu dengan mengamati hasil eksekusi uji data dan fungsional perangkat lunak.

PHP merupakan skrip yang dapat disisipkan ke dalam HTML. PHP banyak digunakan untuk membuat program web dinamis. Selain itu PHP juga dapat digunakan untuk membangun sebuah CMS. Bahasa pemrograman ini diterbitkan pada tahun 1995,

PHP memiliki beberapa keunggulan dibandingkan bahasa pemrograman lain antara lain:

1. PHP bersifat open source sehingga dapat digunakan di berbagai mesin seperti Linux, Unix, Macintosh, Windows dan dapat dijalankan secara runtime melalui console serta dapat menjalankan perintah-perintah sistem

2. PHP adalah bahasa skrip yang tidak melakukan sebuah kompilasi dalam penggunaannya

3. Banyak web server yang mendukung PHP mulai dari apache, IIS, Lighttpd, hingga Xitami dengan konfigurasi yang relatif mudah

4. Pengembangan menggunakan PHP lebih mudah, karena banyaknya milis - milis dan developer yang siap membantu dalam pengembangan

5. PHP mudah dipahami karena scripting yang paling mudah dicari dan memiliki banyak sumber referensi [13].

MySQL yaitu sebuah perangkat lunak sistem manajemen berbasis data SQL Database Management Sistem (DBMS) yang multithread, multi-user, dengan sekitar enam juta instalasi di seluruh dunia. MySQL AB membuat MySQL tersedia sebagai perangkat lunak gratis dibawah lisensi GNU General Public License (GPL), tetapi mereka juga menjual di bawah lisensi komersial untuk kasus-kasus di mana penggunaannya tidak cocok dengan penggunaan GPL. Berbeda dengan proyek-proyek seperti

Apache, di mana perangkat lunak dikembangkan oleh komunitas umum, dan hak cipta untuk kode sumber dimiliki oleh masingmasing penulis, MySQL dimiliki dan disponsori oleh sebuah perusahaan komersial Swedia MySQL AB, di mana memegang hak cipta hampir atas semua kode sumbernya [12].

Blackbox Testing merupakan pengujian yang dilakukan dengan cara mengamati hasil eksekusi melalui data uji dan bertujuan untuk memeriksa kegunaan atau fungsi pada perangkat lunak [2].

\section{Metode Penelitian}

Sistem informasi manajemen persediaan produksi buku berbasis online pada CV Dian Cemerlang ini dibangun dengan menggunakan metode penelitian yang terdiri dari lima tahap yaitu pengumpulan data, analisis data, design sistem, implementasi desain, dan evaluasi sistem.

Tahap pengumpulan data merupakan tahap awal dalam pembuatan sistem informasi manajemen persediaan produksi buku. Tahap pengumpulan data dilakukan dengan cara melakukan pengamatan di tempat dan melakukan wawancara dengan Bapak Yudha selaku direktur CV Dian Cemerlang. Tahap ini dilakukan untuk mengumpulkan data sebanyakbanyaknya, sehingga dapat memudahkan tahap analisis data. Semakin banyak data yang terkumpul, maka semakin mudah untuk menganalisa kebutuhan perusahaan.

Tahap analisis data yaitu tahap di mana data-data yang telah terkumpul dianalisa guna memahami kebutuhan sistem yang ada pada $\mathrm{CV}$ Dian Cemerlang. Data yang dianalisa berupa sistem yang sedang berjalan. Berdasarkan hal itu, penulis membuat usulan sistem untuk melengkapi dan memperbaiki sistem yang sedang berjalan tersebut.

Tahap desain sistem merupakan tahap perancangan usulan sistem yang telah dibuat. Perancangan yang dimaksud meliputi desain user interface (input-output) dan kamus data yang akan digunakan dalam sistem. Hal ini bertujuan menetapkan standar yang sama 
sehingga dapat menyamakan persepsi antara analis dengan programmer.

Tahap implementasi desain merupakan tahap pemrograman. Dalam penelitian ini programmer menggunakan tools PHP versi 5.6.24 dan manajemen database mysql versi

5.0.11. Tahap ini meliputi mastering, transaksi, output dan notifikasi.

Tahap evaluasi sistem yaitu tahap pengujian dan perbaikan sistem yang telah dibangun. Pengujian dilakukan agar modul-modul yang terdapat pada sistem dapat memenuhi tujuan awal yang telah ditetapkan pada tahap analisis. Perbaikan diperlukan jika masih terdapat beberapa modul yang belum memenuhi tujuan awal sistem.

\section{Hasil dan Pembahasan}

Akhirnya penulis berhasil menyelesaikan implementasi desain sistem informasi manajemen persediaan produksi buku berbasis online pada CV Dian Cemerlang ini menggunakan bahasa pemrograman berorientasi objek yaitu PHP dan Mysql. Dalam sistem ini hak akses pengguna dibedakan menjadi 3 seperti tampak pada gambar 1 .

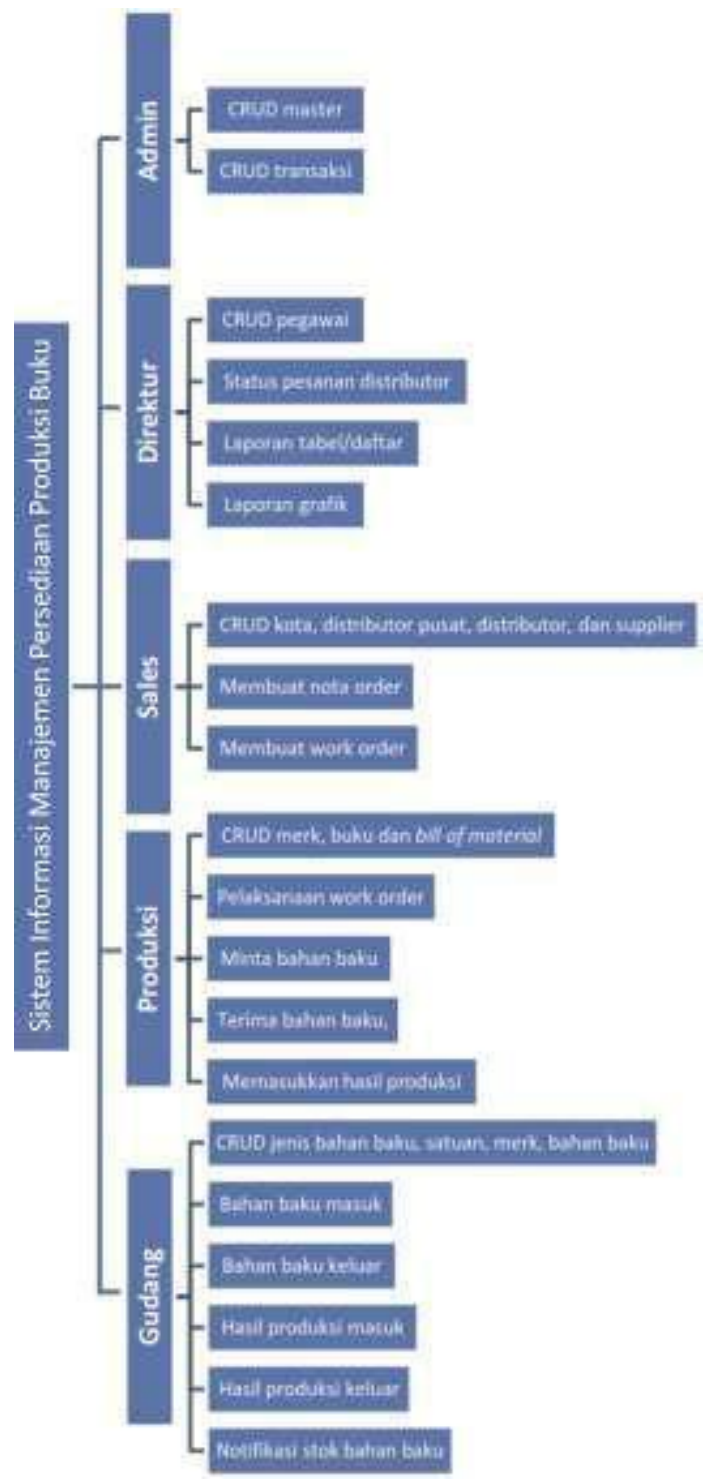

Gambar 1 Pembagian Hak Akses Sistem

Adapun hasil implementasi desain pada penelitian ini adalah sebagai berikut:

Form Nota Order digunakan oleh bagian penjualan untuk memasukkan pesanan para distributor ke dalam sistem. Dalam form nota order, sistem dapat menghitung kebutuhan bahan baku yang diperlukan sesuai dengan pesanan secara otomatis. Selain itu, sistem juga mampu menghitung perkiraan lama pengerjaan buku yang dipesan. Berdasarkan nota order tersebut, sistem secara otomatis membuat work order untuk bagian produksi.

Form Work Order berfungsi untuk memberitahukan pada bagian produksi bahwa ada order atau permintaan untuk memproduksi buku. Setelah itu, bagian produksi membuat permintaan bahan baku yang dibutuhkan sesuai 
dengan permintaan buku pada nota order tersebut. Saat bagian produksi meminta bahan baku, secara otomatis sistem akan memberikan notifikasi untuk bagian gudang dalam bentuk form permintaan bahan baku.

Form Permintaan Bahan Baku digunakan oleh bagian gudang untuk melihat permintaan bahan baku apa saja yang dibutuhkan oleh bagian produksi untuk menyelesaikan sebuah work order. Setelah bahan baku disiapkan, bagian gudang mengirimkan bahan baku tersebut dan secara otomatis bagian produksi menerima notifikasi pemberitahuan bahwa bahan baku yang dibutuhkan telah dikirim.

Pada Form Konfirmasi Bahan Baku bagian produksi harus melakukan konfirmasi apakah bahan baku yang diterima telah sesuai kebutuhan, atau ada beberapa bahan baku yang tidak layak pakai sehingga harus diretur kepada pihak gudang.

Berdasarkan penggunaan dan pemesanan bahan baku di perusahaan, maka terdapat Form Kartu Stok yang berfungsi untuk mencatat bahan baku masuk dan bahan baku keluar pada periode tertentu. Oleh karena itu, tentu saja form ini dilengkapi dengan filter jenis bahan baku dan tanggal.

Pada sistem ini terdapat Form Bahan Baku yang memiliki fitur notifikasi stok kritis yang berfungsi sebagai pemberitahuan untuk bagian gudang bahwa terdapat bahan baku yang jumlahnya kurang dari batas aman, user interface form ini dapat dilihat pada gambar 2.

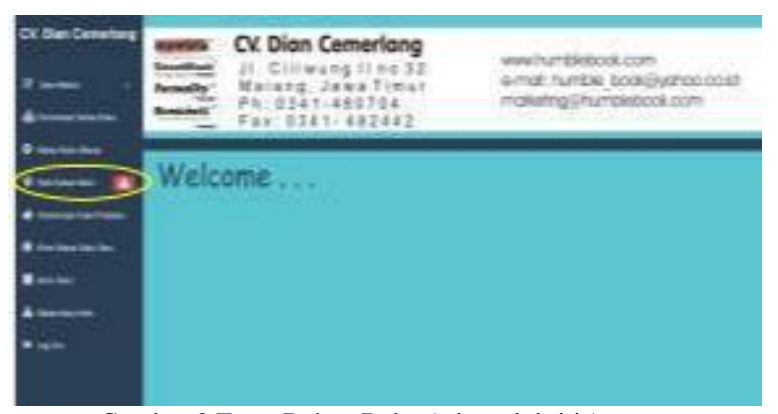

Gambar 2 Form Bahan Baku (ada stok kritis)

Form Hasil Produksi merupakan form yang berfungsi mencatat hasil produksi yang telah selesai dikerjakan bagian produksi. Pada form ini bagian produksi mencatatkan hasil produksi dan sisa bahan baku setelah proses produksi.

Dalam penelitian ini juga terdapat Form Laporan Grafik digunakan untuk memudahkan direktur atau top management dalam memantau perkembangan bisnisnya.

Setelah tahap implementasi desain selesai, maka selanjutnya adalah tahap evaluasi sistem. Tahap ini dilakukan untuk menguji kembali semua tahapan yang sudah dilakukan, sehingga dapat dipastikan bahwa sistem telah dibuat sesuai dengan kebutuhan atau tujuan yang diharapkan.

Sistem yang dibangun telah diuji coba oleh lima orang responden yang terdiri dari satu orang dosen, satu orang awam, dua orang dari pihak CV Dian Cemerlang dan satu orang mahasiswa. Berdasarkan hasil uji coba keseluruhan sistem informasi manajemen persediaan, sebanyak $4 \%$ responden menilai kurang, 35\% responden menilai cukup, dan sebanyak $61 \%$ responden menilai baik. Oleh karena itu, dapat disimpulkan bahwa keseluruhan sistem informasi manajemen persediaan sudah baik.

Setelah tahap implementasi desain dan evaluasi sistem selesai, maka penulis dapat memberikan beberapa catatan terkait kelebihan dan kelemahan yang terdapat pada sistem ini.

Sistem informasi manajemen persediaan produksi buku berbasis online ini memiliki kelebihan yaitu:

1. Sistem sudah menerapkan teknologi berbasis online, sehingga memudahkan user (direktur) memantau kondisi perusahaan secara langsung meskipun sedang tidak berada di perusahaan.

2. Sistem ini dikembangkan dengan menggunakan pemrograman PHP dan Mysql yang dapat dengan mudah dikembangkan oleh peneliti lain jika ingin melengkapinya dengan modul-modul lain guna menghasilkan aplikasi yang lebih baik lagi.

3. Sistem ini dirancang untuk memudahkan perusahaan memantau stok bahan baku dan produk jadi yang tersedia. Secara teknik sistem ini juga memudahkan pengecekan stok kritis, karena akan memunculkan notifikasi dan daftar stok kritis apabila terdapat stok di bawah jumlah minimum. Perusahaan cukup menentukan jumlah minimum bahan baku yang harus tersedia di gudang.

4. Sistem ini juga mendukung pengecekan stok bahan baku secara real time saat customer melakukan pesanan. Jika jumlah bahan baku yang dibutuhkan untuk produksi kurang, maka akan muncul jangka waktu pengiriman 
oleh supplier, sehingga dapat memperkirakan berapa waktu yang dibutuhkan untuk penyelesaian order customer pada saat itu juga.

Sebuah penelitian tentu tidak luput dari kekurangan dan kegagalan, maka dari itu penulis berbesar hati untuk mengungkapkan kekurangan yang terdapat pada penelitian ini. Adapun kekurangan dari sistem informasi manajemen persediaan produksi buku berbasis online ini yaitu:

1. Sistem ini belum mampu memberikan informasi biaya bahan baku untuk setiap order, di mana hal ini juga dibutuhkan untuk memudahkan perusahaan dalam menentukkan harga jual kepada customer mengingat harga bahan baku juga dapat berubah sewaktu-waktu.

2. Sistem ini belum mampu membantu perusahaan dalam memilih bahan baku yang sesuai dengan kriteria buku pesanan dan budget yang dimiliki oleh customer.

3. Sistem ini juga belum dirancang untuk pengembangan aplikasi mobile.

\section{Kesimpulan dan Saran}

\section{Berdasarkan pelaksanaan kegiatan penelitian ini dapat diambil beberapa kesimpulan yaitu:}

1. Sistem yang dibangun mampu mencatat pemakaian bahan baku dan hasil produksi secara real time, sehingga diharapkan dapat membantu perusahaan dalam memantau pemakaian bahan baku dengan lebih akurat dan mengetahui jumlah stok bahan baku dan hasil produksi di gudang.

2. Sistem yang dibangun mampu memberi informasi ketersediaan bahan baku dan memberi notifikasi bila bahan baku berada di bawah batas aman, sehingga dapat meminimalisir risiko kehabisan bahan baku.

Adapun saran-saran yang dapat digunakan untuk menyempurnakan framework sistem informasi ini adalah sebagai berikut:

1. Melengkapi website yang dibuat dengan menanmbahkan fitur perhitungan biaya penggunaan bahan baku.

2. Menambahkan sistem pendukung atau Decision Support Sistem (DSS) untuk memilih bahan baku yang sesuai dengan buku pesanan dan budget yang dimiliki oleh customer.

3. Pengembangan sistem informasi berbasis mobile dengan topik yang sama.

\section{Daftar Pustaka}

[1] Barbara A.C., 2009, Seven Steps to Mastering Business Analysis, J. Ross Publishing.

[2] Blogspot, 14 Maret 2017, "Pengujian Perangkat Lunak", blackwhitetesting.blogspot.co.id/2016/04/black -box-testing.html?m=1

[3] Budiarto, Bangun., dkk, 2016, Perancangan Sistem Informasi Manajemen Stok Makanan dan Minuman pada Restoran NZIP, dipresentasikan pada Seminar Nasional Teknologi Informasi dan Multimedia 2016, Yogyakarta.

[4] Dharmawan, Yanitra Abdi., 2013, Rancang Bangun Sistem Informasi E-Commerce Humblebook (Studi Kasus: CV Dian Cemerlang), Laporan Tugas Akhir, Sistem Informasi, Universitas Ma Chung, Malang.

[5] Djahir, Yulia., Pratita, Dewi., 2015, Bahan Ajar Sistem Informasi Manajemen, Edisi 1, Deepublish, Yogyakarta.

[6] Hutahaean, Jeperson, 2015, Konsep Sistem Informasi, Edisi 1, Deepublish, Yogyakarta.

[7] Kendall \& Kendall., 2012, System Analysis and Design, 8th ed, Pearson Educations, New Jersey.

[8] Muslihudin, Muhamad., Oktafianto, 2016, Analisis dan Perancangan Sistem Informasi Menggunakan Model Terstruktur dan UML, Edisi 1, Penerbit Andi, Yogyakarta.

[9] Natalia, 2016, Sistem Informasi Perhitungan Biaya Bahan baku Produksi Buku (Studi Kasus : CV Dian Cemerlang), Laporan Praktik Kerja Lapangan, Sistem Informasi, Universitas Ma Chung, Malang.

[10] Nugroho, Adi., 2009, Rekayasa Perangkat Lunak Menggunakan UML dan Java, Penerbit Andi, Yogyakarta.

[11] Satzinger, John., 2015, System Analysis and Design in a Changing World, 7th ed, Cengage Learning.

[12] Wikipedia, 10 Maret 2017, "MySQL", https://id.wikipedia.org/wiki/MySQL

[13] Wikipedia, 10 Maret 2017, "PHP", https://id.wikipedia.org/wiki/PHP 